\title{
FOREST ANALYSIS IN THE LANDSCAPE CONTEXT AT SÃO BARTOLOMEU RIVER BASIN, VIÇOSA-MG
}

Joana Angélica Cavalcanti Pinheiro $2^{*} \odot$, Elpídio Inácio Fernandes-Filho ${ }^{\circledR} \odot$ Lucas Carvalho Gomes $^{4} \odot$, Vicente Paulo Soares ${ }^{5}$ (?) and Tathiane Santi Sarcinelli ${ }^{6}$ ()

\footnotetext{
${ }^{1}$ Received on 30.03.2021 accepted for publication on 22.06.2021.

${ }^{2}$ Serviço Geológico do Brasil, Departamento de Hidrologia, Porto Velho, RO - Brasil. E-mail: <joana.pinheiro@cprm.gov.br>.

${ }^{3}$ Universidade Federal de Viçosa, Departamento de Solos, Viçosa, MG - Brasil. E-mail: <elpidio@ufv.br>.

${ }^{4}$ Universidade Federal de Viçosa, Programa de Pós-Graduação em Solos, Viçosa, MG - Brasil. E-mail: <lucas.c.gomes@ufv.br >.

${ }^{5}$ Universidade Federal de Viçosa, Departamento de Engenharia Florestal, Viçosa, MG - Brasil. E-mail: <vicentepsoares@gmail.com>

${ }^{6}$ Suzano S. A, Aracruz, ES - Brasil. E-mail: <tsarcinelli@suzano.com.br>.

*Corresponding author.
}

\begin{abstract}
The reduction of forest areas in recent years has influenced landscape fragmentation, compromising ecosystem functions. The natural forest, in addition to maintaining biodiversity, is capable of improving the hydrological conditions of the watershed. This study aimed to characterize the landscape structure of the remaining forest fragments in the São Bartolomeu river basin, at the Zona da Mata of Minas Gerais State, and to assess their physiographic and pedological representativeness. The study area is responsible for most of Viçosa's water supply, while it is undergoing an urbanization process, reinforcing the need for ordering the use, besides the evaluation of priority areas for conservation. The studies related to the landscape structure were based on the metrics of forest fragments. The representativeness was analyzed regarding the aspects of topographic compartmentation, slope faces, and soils, using the Chi-square test. The natural forest presents fragments varying from medium to large size, with satisfactory proximity between them. However, the forest patches have irregular shapes, favoring the edge effect with a tendency towards irregularity as the fragment size increases. The results of the physiographic and pedological representativeness indicate that the land uses are dependent on the location in the landscape. According to the statistical test, the forest occurs less frequently than expected on the river terraces (48.3\%) and convex slopes (2.3\%), as well as on the Red-Yellow Acrisols $(53.1 \%)$, and on the north $(28.5 \%)$ and west $(20.9 \%)$ faces. For urban planning and biodiversity conservation purposes, it is recommended to balance the forest area in the different compartments of the landscape, giving priority to the connection of forest fragments.
\end{abstract}

Keywords: Landscape structure; Spatial representativeness; Forest fragments.

\section{ANALISE FLORESTAL NO CONTEXTO DA PAISAGEM NA BACIA HIDROGRÁFICA DO RIBEIRÃO SÃO BARTOLOMEU, VIÇOSA-MG}

RESUMO - Nos últimos anos, a redução de áreas florestais tem influenciado na fragmentação da paisagem comprometendo funções dos ecossistemas. A floresta natural, além da manutenção da biodiversidade, é capaz de melhorar as condições hidrológicas da bacia hidrográfica. Sendo assim, o objetivo deste estudo foi caracterizar a estrutura da paisagem dos fragmentos florestais remanescentes e avaliar a sua representatividade fisiográfica e pedológica na bacia hidrográfica do ribeirão São Bartolomeu, Zona da Mata mineira. A região de estudo é responsável pela maioria do abastecimento de água do município de Viçosa, ao mesmo tempo em que está passando por um processo de urbanização, reforçando a necessidade de um processo de ordenação de uso e avaliação de áreas prioritárias para conservação. Os estudos relacionados à estrutura da paisagem foram baseados nas métricas dos fragmentos florestais. A representatividade foi analisada quanto aos aspectos da compartimentação topográfica, das faces de orientação e dos solos, por meio do teste de Qui-Quadrado. A floresta natural apresentou fragmentos de tamanhos médios elevados e boa proximidade entre os fragmentos, contudo com formas irregulares que favorecem o efeito de borda, havendo uma tendencia de irregularidade à medida que se aumenta o tamanho do fragmento. Os resultados das representatividades fisiográficas e 


\begin{abstract}
pedológica mostraram que os usos do solo são dependentes da localização na paisagem. No resultado do teste estatístico, a floresta ocorre com menor frequência que o esperado nos terraços fluviais $(48,3 \%)$ e encostas convexas (2,3\%), nos Argissolos Vermelho-Amarelo (53,1\%) e nas faces norte (28,5\%) e oeste (20,9\%). Para fins de planejamento urbano e conservação da biodiversidade, recomenda-se equilibrar a área florestal nos diferentes compartimentos, dando prioridade à conexão dos fragmentos florestais.
\end{abstract}

Palavras-Chave: Estrutura da paisagem; Representatividade espacial; Fragmentos florestais.

\section{INTRODUCTION}

The forest fragmentation process is associated with land use changes, dictated mainly by urbanization and agricultural occupation. In most landscapes, the sustainable limit of forest fragmentation has already been exceeded and the connectivity reduced. In these cases, the richness and abundance of local species become dependent on the size and environmental quality of the remaining fragments (Pardini et al., 2010).

The reduction of sites with landscape-specific pedological and physiographic characteristics is one of the consequences of forest fragmentation (Sarcinelli et al., 2012). Then, the organisms are generally in restricted and specific environments, resulting in landscapes with little habitat diversity (Fahrig, 2003). Therefore, topographic and edaphic variations play an important role in the spatial organization of tree vegetation on a local scale (Martins et al., 2003).

The isolation of the remaining forests fragments hinders the dispersion of the species, reducing the gene flow, genetic variability, and adaptability of these species (Guariz and Guariz, 2020). To mitigate these effects, it is essential to develop research and actions that result in practices for the development of a sustainable environment.

Landscape characterization applies several methods and techniques of metrics to analyze the landscape and can give important insights for the adequate management of natural resources (França et al., 2019). For instance, the representativeness of the environmental diversity (Sarcinelli et al., 2012) is used better understand the dynamics of the landscape structures. This approach is based on ecosystem ecology and spatial modeling and had a major advance with the rapid development of Remote Sensing and Geographic Information Systems.

Landscape-based conservation studies are essential for various purposes, such as delimitation of ecological corridors and landscape connectivity (Guariz and Guariz, 2020; Salomão et al., 2018; Schackelford et al., 2018); analysis of spatial planning and protection of environmental services (Inkoom et al., 2018); recovery of degraded areas (Paula et al, 2015; Toledo et al., 2018); wildlife management (Kosicki, 2018; Morelli et al., 2018); and planning of urban areas (Ribeiro et al., 2020). Therefore, these studies give the basis for proper management of resources within the context of the landscape.

Currently, the São Bartolomeu river is responsible for much of the water supply of about $70 \%$ of the municipality's population in the rainy season and $30 \%$ in the dry season of Viçosa, located in the Zona da Mata of Minas Gerais State (Bastos et al., 2009). The trend of urban expansion in the basin can accelerate the process of forest fragmentation if environmental criteria in urban planning are not well defined. Then, the adoption of measures to preserve biodiversity and the proper functioning of the region's water system are essential for human well being in this basin. This study aimed to characterize the structure of the remaining forest fragments and to evaluate their physiographic and pedological representativeness, and support the definition of priority areas for forest conservation.

\section{MATERIALS AND METHODS}

\subsection{Study area}

The São Bartolomeu river basin is located in the municipality of Viçosa, Zona da Mata de Minas Gerais, between the parallels $20^{\circ} 44^{\prime}$ and $20^{\circ} 51^{\prime}$ South Latitude and meridians $42^{\circ} 55^{\prime}$ and $42^{\circ} 50^{\prime}$ Longitude West of Greenwich (Figure 1). This basin is located in the Atlantic Forest biome and covers about 2,800 hectares, with an altitude ranging from 655 to 894 $\mathrm{m}$. The Montana Semidecidual Seasonal Forest is the main forest natural typology (Veloso et al., 1991), and the region is characterized by intense agricultural activity developed by small farmers and, more

Revista Árvore 2021;45:e4533 
recently, urban expansion, with the implementation of condominiums and allotments. The climate is Cwa type, with rainy summers and cold and dry winters (Martins et al., 2018). The geology in this study region is characterized by the predominance of graniticgnaissic substrate (Ab'Saber, 1970), and geoforms with an asymmetric concave-convex-top sequence and steep part of the slopes (Rezende, 1971).

For this study, we used the land use land cover map developed by Moreira (2009) from the visual classification of Ikonos II image georeferenced and orthorectified with PEC Class A for the scale of 1:10,000 (Santos, 2008). The land use land cover classification resulted in nine categories: agriculture, urban area, rural buildings, coffee, native forest, planted forest, hydrography, pasture, and pathways. The scale used in this work allows mapping fragments smaller than 1 ha accurately.

\subsection{Description of landscape structure}

Using the land use land cover maps, we analyzed the landscape structure based on several metrics of the forest fragments: total class area (CA), average fragment size (MPS) - including standard deviation (PSSD) and coefficient of variation of sizes (PSCoV) -, number of fragments (NumP), shape index (MSI), Area-Weighted Mean Shape Index (AWMSI), total edge (TE), edge density (ED), proximity indexes (MPI, with distance of $500 \mathrm{~m}$, and MNN) and central area index (TCAI). These metrics were derived using the Patch Analyst extension of Arcgis 10.1 software,

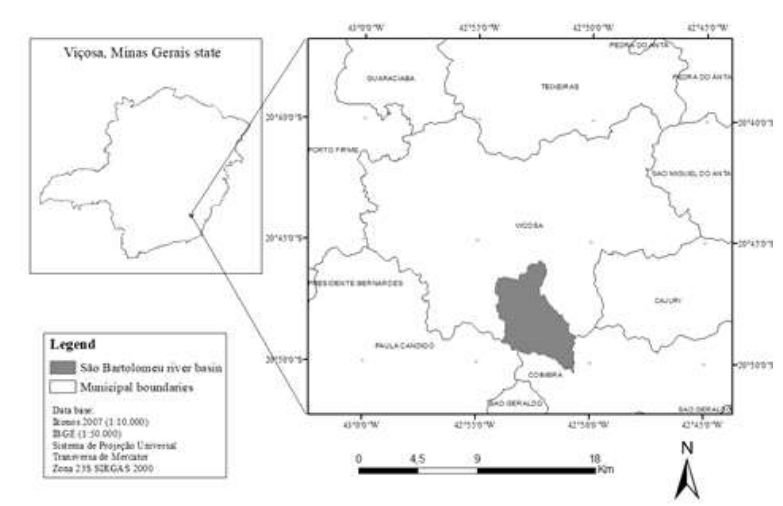

Figure 1 - Watershed of the São Bartolomeu river, Viçosa, Minas Gerais, Brazil.

Figura 1 - Localização da bacia hidrográfica do ribeirão São Bartolomeu, Viçosa-MG. which requires the land use land cover map and applies specific equations for each metric based on the Fragstats (Spatial Pattern Analysis Program for Quantifying Landscape Structure) developed by McGarigal and Marks in 1995.

First, the analysis was conducted considering different size classes of forest fragments: less than 1 ha, 1 to 9.99 ha, 10 to 19.99 ha, 20 to 39.99 ha, 40 to 79.99 ha, and bigger than 80 ha. Subsequently, we conducted an individual analysis of the fragments bigger than 40 ha since they had great relevance in the land cover and higher stability due to the nuclear area. The edge effect considered for forest fragments was 62 meters, which was the average value of the interval (50- $78 \mathrm{~m}$ ) obtained by Lemos (2008) in a region near the studied basin.

\subsection{Physiographic and pedological representativeness of land uses}

To increase the details of our analysis, we generated a DEM (Digital Elevation Model) in the ArcGIS 10.1 Topo to Raster interpolator with 5 x 5 $m$ resolution using the level curves ( 5 meters) and the mapped hydrography as inputs. The level curves, with class A altimetric accuracy, were obtained from the digital restitution of the Ikonos II image from October 2007. The hydrography was obtained by visual mapping of the Ikonos image, with the aid of the image available in Google Earth (Digital Globe, 2013), of the level curves and the hydrography mapped from IBGE. Field visits were performed with GPS to ensure the correct mapping of hydrography in places considered visually non-conclusive.

The analysis of representativeness of land use was analyzed by the compartmentalization of the relief in relation to geomorphology, exposure faces, and soils. For automatic segmentation of relief forms, we combined the attributes of the slope, curvature, accumulated surface flow and Euclidean distance to the waterways to identify four morphological units: hilltops, river plains, and terraces, concave and convex slopes. The criteria of automatic segmentation, adopted by Sarcinelli et al. (2012), had the limits of the variables adjusted according to the regional specificities of the relief of the research site.

The representativeness of the land use land cover in the various faces of exposure was analyzed 
Table 1 - Class-level landscape structure for the size classes of forest fragments.

Tabela 1 - Estrutura da paisagem em nivel de classe para os as classes de tamanho dos fragmentos florestais.

\begin{tabular}{|c|c|c|c|c|c|c|c|}
\hline Metrics & Unit & $<1$ ha & $1-10$ ha & $10-20$ ha & $20-40$ ha & $40-80$ ha & $>80 \mathrm{ha}$ \\
\hline$\overline{\mathrm{CA}}$ & ha & 15.1 & 159.2 & 80.3 & 186.0 & 233.6 & 234.6 \\
\hline MPS & ha & 0.6 & $4 . .4$ & 16.1 & 31.0 & 58.4 & 234.6 \\
\hline NumP & units & 26.0 & 36.0 & 5.0 & 6.0 & 4.0 & 1.0 \\
\hline PSSD & ha & 0.3 & 2.8 & 2.7 & 6.3 & 7.9 & 0.0 \\
\hline PSCoV & $\%$ & 45.5 & 62.8 & 16.9 & 20.3 & 13.5 & 0.0 \\
\hline TE & $\mathrm{m}$ & 12825.3 & 44022.0 & 16031.0 & 32410.5 & 31166.0 & 18682.9 \\
\hline ED & $\mathrm{m} / \mathrm{ha}$ & 14.1 & 48.4 & 17.6 & 35.7 & 34.3 & 20.6 \\
\hline MSI & ad. & 1.9 & 1.7 & 2.3 & 2.7 & 2.9 & 3.4 \\
\hline AWMSI & ad. & 1.4 & 1.3 & 1.3 & 1.4 & 1.3 & 1.3 \\
\hline MPI & ad. & 2.91 & 168.47 & 0 & 12581.25 & 3134.43 & 0 \\
\hline TCAI & $\%$ & - & 7.9 & 21.1 & 28.0 & 24.7 & 61.5 \\
\hline$\overline{\mathrm{NCA}}$ & units & - & 24.0 & 6.0 & 8.0 & 18.0 & $\overline{3.0}$ \\
\hline
\end{tabular}

from the exposure face map with results obtained in degrees with a specific notation for each class: flat $(<$ $3 \%$ slope); North $\left(0-45^{\circ}\right.$ and $\left.315-360^{\circ}\right)$; East (45 - $\left.135^{\circ}\right)$; South $\left(135-225^{\circ}\right)$; and West $\left(225-315^{\circ}\right)$. For the analysis of pedological representativeness of soil uses, we used the soil map produced by Bastos et al. (2009), and the key to identification of the classes was based on the soil/landscape model of the region as proposed by Corrêa (1984).

\subsection{Statistical analysis}

Statistical analysis of the representativeness was analyzed by identifying whether the forest fragments were well represented in relation to the attributes evaluated in each of the three compartmentalities. A contingency table was generated with the number of cells that each class of variables analyzed occupies in each of the land uses present in the basin. The relative deviations were analyzed concerning the expected values for the forest fragments in the compartmentalities performed. The Chi-Square test was performed to verify whether the observed absolute frequency of a variable differed significantly from the expected absolute frequency distribution, according to Equation 1:

$x^{2}=\sum\left\lfloor\frac{(o-e)^{2}}{e}\right\rfloor$

Eq.1

Where, "o" represents the frequency observed for each class and "e" the expected frequency for each class.

\section{RESULTS}

\subsection{Analysis of landscape fragmentation by size class}

In general, natural forests presented fragments of high medium sizes and good proximity between the fragments. Approximately 33\% of forest fragments have a dimension of less than 1 hectare (Table 1). On the other hand, the class of larger size (greater than 80 ha), has only one forest fragment (234.6 ha). In this fragment is located the Forest of Paraíso

Table 2 - Landscape structure for the largest forest fragments.

Tabela 2 - Estrutura da paisagem para os maiores fragmentos florestais.

\begin{tabular}{|c|c|c|c|c|c|c|}
\hline \multirow[t]{2}{*}{ Group } & \multirow[t]{2}{*}{ Units } & \multicolumn{3}{|c|}{ Forest fragments } & \multirow[b]{2}{*}{4} & \multirow[b]{2}{*}{5} \\
\hline & & 1 & 2 & 3 & & \\
\hline $\mathrm{CA}$ & ha & 45.2 & 60.1 & 63.0 & 65.3 & 234.6 \\
\hline TE & $\mathrm{m}$ & 5957.7 & 6530.1 & 11577.0 & 7101.3 & 18682.9 \\
\hline $\mathrm{DE}$ & $\mathrm{m} / \mathrm{ha}$ & 6.6 & 7.2 & 12.7 & 7.8 & 20.6 \\
\hline MSI & ad. & 2.5 & 2.4 & 4.1 & 2.5 & 3.4 \\
\hline AWMSI & ad. & 1.34 & 1.32 & 1.40 & 1.33 & 1.34 \\
\hline $\mathrm{MNN}$ & $\mathrm{m}$ & 23.0 & 10.0 & 572.0 & 19.0 & 5.0 \\
\hline TCAI & $\%$ & 39.0 & 45.1 & 18.9 & 48.5 & 61.5 \\
\hline NCA & units & 1 & 1 & 5 & 1 & 3 \\
\hline
\end{tabular}

Revista Árvore 2021;45:e4533 
Table 3 - Relative deviations between the observed and expected values obtained for the Chi-square test for soil uses in different compartments.

Tabela 3 - Desvios relativos entre os valores observados e esperados obtidos para o teste do Qui-quadrado para os usos do solo em diferentes compartimentações.

\begin{tabular}{|c|c|c|c|c|c|c|c|}
\hline Compartments & Agriculture & Urban area & Building areas & Coffe & Native Forest & Planted Forest & $\overline{\text { Pasture }}$ \\
\hline \multicolumn{8}{|c|}{ Geomorphological } \\
\hline Hill tops & -41.0 & -27.4 & -64.3 & 37.9 & 28.3 & -10.7 & -15.8 \\
\hline Terraces & 146.8 & 115.9 & 252.9 & -69.9 & -40.0 & -83.9 & 5.8 \\
\hline Convex slopes & 7.6 & 2.1 & -11.5 & 3.9 & -9.6 & 10.3 & 4.5 \\
\hline Concave slopes & -26.5 & -19.0 & -25.6 & 0.2 & 8.8 & 12.5 & -0.5 \\
\hline Mean & 55.5 & 41.1 & 88.6 & 28.0 & 21.7 & 29.4 & 6.6 \\
\hline \multicolumn{8}{|c|}{ Pedological } \\
\hline Red-Yellow Acrisol & 158.9 & 193.1 & 220.7 & -37.5 & -60.1 & -77.9 & 6.4 \\
\hline Haplic Cambisol & -27.4 & -33.9 & -38.7 & 9.1 & 10.1 & 14.4 & -1.4 \\
\hline Red-Yellow Ferralsol & -87.0 & -84.0 & -100.0 & -77.9 & 42.2 & 8.7 & 7.0 \\
\hline Mean & 91.1 & 103.7 & 119.8 & 41.5 & 37.5 & 33.7 & 4.9 \\
\hline \multicolumn{8}{|c|}{ Exposure faces } \\
\hline$\overline{\text { Flat }}$ & 77.7 & 310.3 & 60.9 & -75.3 & 4.8 & -74.8 & -27.6 \\
\hline North & 0.3 & 21.0 & 0.1 & 45.1 & -28.5 & 2.6 & 11.4 \\
\hline East & -7.5 & -14.1 & -4.9 & 26.6 & 10.1 & 38.1 & -12.4 \\
\hline South & -6.1 & -68.6 & 4.2 & -39.2 & 47.6 & -54.2 & -17.8 \\
\hline West & 22.9 & 14.4 & -5.3 & -32.9 & -20.9 & 11.0 & 18.8 \\
\hline Mean & 22.9 & 85.7 & 15.1 & 43.8 & 22.4 & 36.2 & 17.6 \\
\hline
\end{tabular}

Research, Training and Environmental Education Station, which is responsible for an area of 194 ha of forest area. Although there are few large fragments, fragments with areas greater than 40 ha total cover approximately $51.6 \%$ in relation to the total forest.

The average size of the fragments increased with the increase of the size classes, as well as the standard deviation of the sizes, however, the fragments smaller than 10 ha (Table 1) presented a high coefficient of variation. The shape of the fragments tended to be more irregular in the smallest fragments and with a lower proportion of the nuclear area.

The landscape metrics of the five largest fragments (with areas greater than $40 \mathrm{ha}$ ) are presented in Table 2, and fragments between 45.2 and 234.6 ha were observed. The edge indexes of the fragments have higher values in fragments 3 and 5, and they also had the most irregular forms.

Fragment 3 had the lowest central area index $(18.9 \%)$ and resulting in 5 distinct nuclear areas. In contrast, fragments 1,2 , and 4 presented similar central areas index and only one nuclear area for each. Fragment 5 presented the highest index of central area, with a value of $61.5 \%$, distributed in 3 nuclear areas. The proximity index has led to the fragments being well connected, except for fragment 3 , which has $572 \mathrm{~m}$ from the nearest fragment.

\subsection{Representativeness of physiographic and pedological attributes}

The spatial relationship between land use and topographic, pedological, and face compartmentalization (with 18, 12, and 24 degrees of freedom, respectively) was not significant according to the values of Chi-square tests at $95 \%$ probability. The topographic compartmentalization (Table 3, Figure 2a) showed that there was a much lower occupation of forests $(40.0 \%)$ in the areas of river terraces than expected. In the areas of convex slopes, there were also native forests with values below the expectations, with a deviation of $9.6 \%$. The forest occupies more frequently than expected the areas of hilltops $(28.3 \%)$ and concave slopes $(8.8 \%)$.

The statistical analysis of pedological compartmentalization (Figure 2b) showed that forest has low representativeness in the areas of Red-Yellow Acrisols, with a value of $60.1 \%$ below the expected. In the Red-Yellow Ferralsols, the forest was represented with $42.2 \%$ of occurrence more than expected, and this result was positive in terms of soil water storage. In the Region of Haplic Cambisols, the forest representation value was $10.1 \%$ higher than expected (Table 3). The forest presented higher values than expected on the south, east, and flat faces (47.6, 10.1, and $4.8 \%$, respectively) for the compartmentalization 


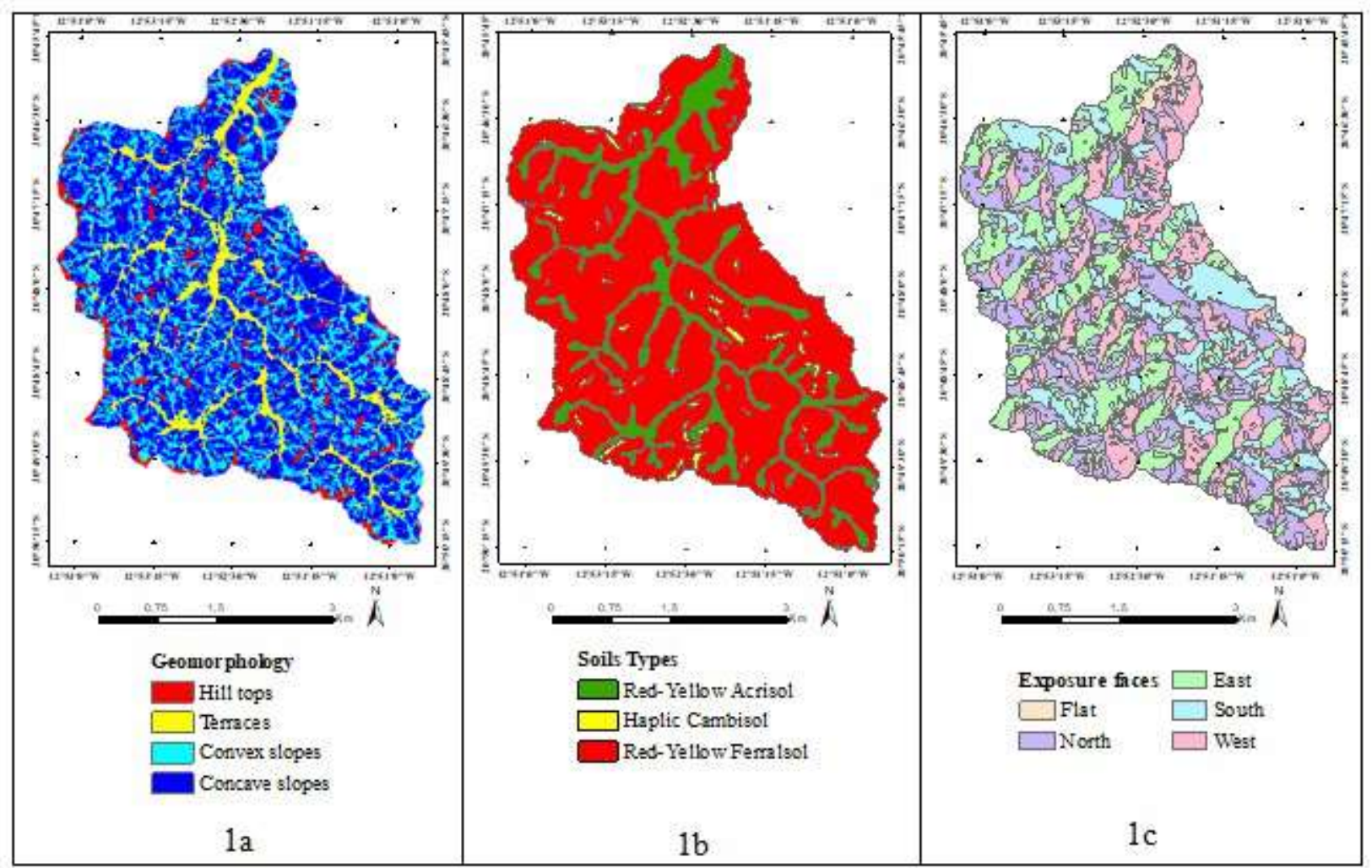

Figure 2 - Geomorphological, soil types and exposure faces compartments, respectively, in São Bartolomeu river basin, Viçosa-MG.

Figura 2 - Compartimentaçôes geomorfológica, dos tipos de solos e das faces de orientação do relevo, respectivamente, na bacia hidrográfica do ribeirão São Bartolomeu, Viçosa-MG.

of the exposure faces, and values below the expected in the north and west faces, especially the north face with $28.5 \%$ less than expected (Table 3, Figure $2 \mathrm{c}$ ).

\section{DISCUSSION}

\subsection{Landscape structure}

Most of the forest fragments present in the São Bartolomeu river basin do not have sufficient size and/or shape to maintain a nuclear area, which may be insufficient to maintain the biodiversity of most plant and animal species. Each species has its particular characteristics in terms of area and habitat types for survival (Fahrig, 2003) associated with food, shelter, and reproduction. A forest fragment of 25ha is the minimum size suggested for the floristic stability in the Atlantic forest biome (Metzger, 1997). However, smaller fragments reduce the isolation of forest fragments in the landscape and help to maintain the regional biodiversity, functioning as ecological trampolines (Ribeiro et al., 2020). With the increase of fragments' area, expressed in size classes, they became rarer and thus representing a lower frequency class in the landscape. This indicates the occurrence of few source areas for the maintenance of populations established in smaller fragments. The area of a fragment is, in general, the most important parameter to explain species richness variations (Pirovani et al., 2014). To Ribeiro et al. (2020), these larger remnants are of great importance for the maintenance of biodiversity and should be the focus of conservation projects. Therefore, the large fragments of the São Bartolomeu river basin have great ecological importance, highlighting the forest fragment in the Mata do Paraíso.

Among the indexes analyzed, the edge densities had more discrepant values among the size classes, with the larger classes presenting lower edge effects and lower susceptibility to external disturbances. The impact of the border effect is related

Revista Árvore 2021;45:e4533 
to the shape of the fragment, the larger the border being the more irregular the shape. The smaller the fragment or the longer the fragment, the stronger the edge effect, as the inner/margin ratio decreases. The excess of edges represents an ideal situation for the development of species of exotic grasses that successfully inhabit the environment (Salomão et al., 2018).

The forest fragments showed a tendency of shape irregularity as the size class increased, intensifying the edge effect, and this situation was also observed by Oliveira (2011). Moreira (2009), working in the area of the São Bartolomeu river basin, found through the circularity index (CI) that the forest fragments had a strong edge effect, with 66 of the 78 fragments presenting elongated shape with CI below 0.503 .

Our study found only 59 nuclear areas considering the edge effect of $62 \mathrm{~m}$. However, the smaller fragments are considered important due to the proximity to large fragments, fulfilling the role of insulating reducers in fragmented landscapes, which can connect the fragments by corridors or serving as stopping sites of migrating organisms (Guariz and Guariz, 2020). According to Pirovani et al. (2014), more regular fragments minimize the ratio border/ area, and therefore, the central area is farther from the edges and isolated from external factors, influencing the quality of the structure of these ecosystems in the future.

Fragment 3 presented the most irregular shape and higher values of edge indexes among the largest fragments, mainly due to its very jagged perimeter. The central area index reinforced the fragility situation of fragment 3 , resulting in a division of the fragment into 5 distinct nuclear areas. In addition, it presented more isolation in relation to the others. In general, a low degree of isolation of the native forest was obtained, and it can be translated into great possibilities of interaction between the fragments, through the dispersion of propagules and the flow of animals. According to Gustafson and Parker (1994), a reduction in isolation produces exponential increases in the index, and the increase in the size of these fragments produced a more modest linear increase in the index. Metzger (1997) mentions that the connectivity between fragments is an important physical factor related to variations in tree species richness. Isolated communities may exhibit very variable composition and slow recovery patterns, but connectivity between disturbed fragments has increased disturbance resistance (Schackelford et al., 2018).

\subsection{Physiographic and pedological representation}

The curvature of the terrain influences the erosive power of the water flow on the surface, and also the water dynamics through the soil profile. We found that the forest occurs in concave areas more frequently than expected, being this result a good indicator for water conservation. In the concave areas occurs the convergence of the water flow, favoring erosive processes that result in grooves and can evolve in a gully. According to Chagas et al. (2013), soils tend to become saturated, and infiltration occurs in the lower parts of the slope and the elevated concave positions (surface flow of convergent water). The concave surfaces are characterized by microclimatic, topographic, and solar radiation conditions and accumulation of water, sediments, minerals and organic matter may occur in this pedoform (Aumond and Maçaneiro, 2014). This situation favors the occurrence of species with higher nutritional requirements and water demand. In contrast, the convex slopes present divergent water surface flow and favor laminar erosion. The lower percentage of native forest $(8.8 \%)$ in the convex slopes than the expected results in lower problems related to erosion and formation of the formation of gullies, but the restoration of these areas with natural vegetation can provide greater soil stability by reducing laminar erosion, especially in the high slope areas.

The terraces along the watercourses are associated with Acrisols and a low slope ( $0-8 \%)$ and are preferred for occupation by residence and agriculture (Ippoliti et al., 2005). However, Souza et al. (2013) found that flat areas presented less erosion, highest diversity indexes, and higher numbers of rare species. The region of terraces with Red-Yellow Acrisols present in the basin, associated with the low occurrence of forest, are considered priority areas in forest recovery planning. Increase forest in these areas can favor biodiversity, but also protect the watercourses and the quality of water resources.

The forest representativeness in the Ferralsols promotes positive results in terms of water storage in the soil since Ferralsols have a great water storage 
capacity due to their physical nature. Ferralsols have a soil physical structure with high porosity and provide optimal conditions for water infiltration and percolation through the soil profile (Brandão et al., 2006). The Red-Yellow Ferralsols were also found on the tops, wavy slopes, and inclined planes.

Ippoliti et al. (2005), in a study in the municipality of Viçosa-MG, observed that the Red-Yellow Ferralsols of flattened tops are generally deeper and developed, while in lower parts, especially in the lower third of the elevations, it can still be deep in convex-convex pedoforms or be shallow in convexconcave pedoforms. In the tops of hills, the high forest representativeness can be associated with the Ferralsols of the flattened tops, being important for its high water storage capacity in the soil profile.

The Haplic Cambisols occupy the steepest slopes of the landscape, being shallow soils and more susceptible to erosion, often with exposure of the C horizon. Rezende (1971), in studies in the Zona da Mata Mineira, highlighted that Cambisols located in the very steepest areas are the least thick of the sequence, because this position favors morphogenesis, leading these soils to a constant rejuvenation by erosion. Our study shows that the forest presence in these areas was satisfactory and since the water surface flow is favored and can trigger erosive processes and cause the reduction of water quality, the proper soil use and management in these areas are extremely important.

In the Southern Hemisphere, the sun has an apparent east-west trajectory with declination to the north, and it results in solar light tending to intercept the surfaces facing north and tangentially those facing south (Ferreira et al., 2005). According to this author, this effect will be more pronounced in areas with wavy relief. Knowing that the angle of incidence of the sun's light promotes changes in the amount of heat transmitted (Bonan, 2002), the surfaces facing north receive more energy than those facing the south, tending to have higher potential evapotranspiration and lower soil moisture.

In this study, the forest presented the lowest representativeness on the north face, which may represent losses of forest species that require a higher incidence of solar radiation and adapted to drier soils. Due to the lower protection of areas with lower water availability, populations of species not tolerant to flooding or the high water table may be underrepresented (Sarcinelli et al., 2012).

The east and west faces presented differences related to the time of solar radiation incidence since the total amount of incidence time is the same. The eastern face receives radiation in the morning, a period from thermal inertia from the night before, presenting lower temperatures and favor the maintenance of soil moisture. Because the natural vegetation is distributed predominantly on the flat areas, eastern and southern faces, good representativeness of forest species adapted to humid and more shaded environments is expected.

In general, the places with a higher incidence of solar radiation, mainly located in more fertile soils associated with convergent water flow regions and deposition areas, had low natural vegetation, being therefore considered niches of rare presence in the landscape associated with fauna and flora. Batista et al. (2009) highlight that studies based only on the most preserved fragment(s), as commonly occurs in management plans, do not guarantee the conservation of the natural diversity of land and the vegetation gradient that determine local biodiversity.

Production of water associated with biodiversity conservation is one of the main ecosystem services of the São Bartolomeu river basin. Then, it is necessary to ensure forest representativeness in all types of environments of the basin, favoring the sustainability and resilience of natural vegetation associated with good hydrological conditions, ensuring the interaction of processes between forest fragments and, consequently, of the landscape as a whole. Native forests promote the production and conservation of water sources, favoring the reduction of peak runoff, distributing their occurrence in a longer period of the year with good quality water. Silva et al. (2020) corroborate that actions are needed aiming to recover the recharge potential in the basin, especially with a focus on conservation practices that foster soil protection and appropriate land use land cover in the contribution area of the São Bartolomeu river basin.

\section{CONCLUSIONS}

The forest fragments present good proximity, however, they have irregular shapes that favor the edge effect. The existence of few source areas

Revista Árvore 2021;45:e4533 
for the maintenance of populations established in smaller fragments is different from the importance of connectivity between the fragments. Therefore, the management in this basin should take these fragments into account as a way to connect with large fragments and improve regional biodiversity. Although the study of landscape structure is of fundamental importance, habitat divisions in the fragmentation process may not be sufficient to understand the effects on biodiversity, as it does not consider the diversity of niches and landscape compartments.

The largest forest fragments present the highest rates of nuclear area, showing that these fragments are large enough to minimize the effects of edge and generate fragments with large nuclear areas. Therefore, these large fragments must be conserved in management planning aiming at water conservation and biodiversity protection,

Among the five largest fragments, a fragment showed results that indicate the need for practices that improve its stability, such as forest restoration and land uses in the surroundings that decrease disturbances and other conservation measures.

The distribution of forest fragments in specific niches in relation to soil type, facing slopes and geomorphology should be associated with studies that support the decision about priority areas for forest conservation. In general, our study shows that there is a compartmentalization that may not guarantee the maintenance of biodiversity. In order to increase the spatial representativeness of the native forest in the landscape, forest use should be a priority in the terraces (riparian forests) nearby the rivers and associated with the Red-Yellow Acrisols, convex slopes, and on the north and west faces. However, there must be a balance in the different compartments, associating with forest connectivity and landscape structure.

\section{AUTHOR CONTRIBUTIONS}

Pinheiro, J. A. C. - organization, data processing, analysis of results and writing. Fernandes-Filho, E. I. - conceived the ideas, contributed to design the methodology and to the writing. Gomes, L. C. contributed to the writing and translation. Soares, V, P. and Sarcinelli, T. S. - conceived the ideas and contributed to the writing.

\section{REFERENCES}

Ab'Saber AN. Províncias geológicas e domínios morfoclimáticos no Brasil. Geomorfologia. 1970;(20):1-26.

Aumond JJ, Maçaneiro JP de. Systemic approach and roughness application to cause emerging properties in the restoration of degraded soils. Ciência florestal. 2014;24(3):759-770. doi: 10.1590/1980509820142403023

Batista ER, Santos RF dos, Santos MA dos. Constructing landscape scenarios to the national park Serra da Bocaina. Revista árvore. 2009;33(6):10951108. doi: 10.1590/S0100-67622009000600012

Bastos RKV, Bevilacqua P, Mounteer AH, Vieira CAO, Fernandes Filho E, Oliveira JC, et al. Relatório de implantação do Plano de Segurança da Água: Projeto Piloto Brasil - PSA/UFV. Viçosa: Universidade Federal de Viçosa; 2009.

Brandão VS, Silva DD da, Ruiz HA, Pruski FF, Schaefer CEGR, Martinez MA, et al. Crust hydraulic resistance in soils under simulated rain. Revista brasileira de ciência do solo. 2006;30(1):13-22. doi: 10.1590/S0100-06832006000100002

Bonan GB. Ecological climatology: Concepts and applications. New York: Cambridge University Press; 2002.

Chagas CS, Fernandes Filho EI, Bhering SB. Relationship between terrain attributes, parent material and soils in an area in the Northwest of Rio de Janeiro State (Brazil). Sociedade e natureza. 2013;25(1):147-162. doi: 10.1590/s198245132013000100012

Corrêa GF. Modelo de evolução e mineralogia da fração argila dos solos do planalto de Viçosa, MG [dissertação]. Viçosa, MG: Universidade Federal de Viçosa. Viçosa, 1984.

Fahrig L. Effects of habitat fragmentation on biodiversity. Annual review of ecology, evolution and systematic. 2003; 34:487-515. doi: 10.1146/ annurev.ecolsys.34.011802.132419

Ferreira FP, Azevedo AC de, Wappler D, Kanieski AJ, Girelli D, Pedrotti J. Solar exposure and soil properties in Santa Maria - RS. Revista brasileira 
de agrociência. 2005;11(3):377-381. doi: 10.18539/ CAST.V11I3.1268

França LCJ, Morandi DT, Menezes ES, Mucida DP, Silva MD da, Lisboa GS. Landscape ecology applied to territorial order and forest management: methodological procedures. Revista nativa. 2019;7(5):613-620. doi: 10.31413/nativa.v7i5.7363

Guariz HR, Guariz FR. Evaluation of the size and shape of forest fragments using landscape metrics for the municipality of São Roque do Canaã, Northwest of Espírito Santo State. Revista brasileira de geografia física. 2020;13(5):2139-2153. doi: 10.26848/rbgf.v13.5.p21392153

Gustafson EJ, Parker GR. Using an index of habitat patch proximity for landscape design. Landscape and urban planning. 1994;29(2-3):117- 130. doi: 10.1016/0169-2046(94)90022-1

Inkoom JN, Frank S, Greve K, Walz U, Fürst C. Suitability of different landscape metrics for the assessments of patchy landscapes in West Africa. Ecological indicators. 2018;85:117-127. doi: 10.1016/j.ecolind.2017.10.031

Ippoliti GA, Costa LM da, Schaefer CEGR, Fernandes Filho EI, Gaggero MR. Digital terrain analysis: Tool for pedoform identification in the "mar de morros" watershed (MG). Revista brasileira de ciência do solo. 2005;29:269-276. doi: 10.1590/ S0100-06832005000200012

Kosicki JZ. Are landscape configuration metrics worth including when predicting specialist and generalist bird species density? A case of the generalized additive model approach. Environmental modeling \& assessment. 2018;23(2):193-202. doi: $10.1007 / \mathrm{s} 10666-017-9575-1$

Lemos PHD. Efeito de borda no componente arbóreo de um fragmento de floresta decídua, Viçosa, MG [dissertação]. Viçosa, MG: Universidade Federal de Viçosa. Viçosa, 2008.

Martins FB, Gonzaga G, Santos DF, Reboita MS. Climate classification of köppen and thornthwaite for Minas Gerais: current climate and climate changes projections. Revista brasileira de climatologia. 2018;1:129-156. doi: 10.5380/abclima. v1i0.60896

Martins SV, Silva NRS, Souza AL, Meira Neto JAA.
Tree species distribution in a topographical gradiente of tropical semideciduous forest in Viçosa, MG. Scientia forestalis. 2003;(64):172-181.

McGarigal K, Marks BJ. FRAGSTATS. Spatial analysis program for quantifying landscape structure. USDA Forest Service General Technical Report PNW-GTR-351. 1995.

Metzger J.P. Relationships between landscape structure and tree species diversity in tropical forests of South-East Brazil. Landscape and urban planning. 1997;37(1-2):29-35. doi: 10.1016/S01692046(96)00367-2

Moreira AA. Mapeamento de Áreas de Preservação Permanente e dos conflitos de uso da terra em propriedade rurais [tese]. Viçosa, MG: Universidade Federal de Viçosa. Viçosa, 2009.

Morelli F, Benedetti Y, Šímová P. Landscape metrics as indicators of avian diversity and community measures. Ecological Indicators. 2018;90:132-141. doi: 10.1016/j.ecolind.2018.03.011

Oliveira LT. Caracterização da fragmentação florestal para produção de sementes no entorno capixaba do Parque Nacional do Caparaó [monografia]. Jerônimo Monteiro, ES: Universidade Federal do Espírito Santo. Jerônimo Monteiro, 2011.

Pardini R, Bueno AA, Gardner TA, Prado PI, Metzger JP. Beyond the fragmentation threshold hypothesis: regime shifts in biodiversity across fragmented landscapes. Plos one. 2010;5(10):1-10. doi: 10.1371/journal.pone.0013666

Paula MD, Groeneveld J, Huth A. Tropical forest degradation and recovery in fragmented landscapes - Simulating changes in tree community, forest hydrology and carbon balance. Global ecology and conservation. 2015;3:664-677. doi: 10.1016/j. gecco.2015.03.004

Pirovani DB, Silva AG da, Santos AR dos, Cecílio RA, Gleriani JM, Martins SV. Spatial analysis of forest fragments in the Itapemirim River Basin, ES. Revista Árvore. 2014;38(2):271-281. doi: 10.1590/ S0100-67622014000200007

Rezende SB. Estudo de crono-toposeqüências em Viçosa-Minas Gerais [dissertação]. Viçosa, MG: Universidade Federal de Viçosa. Viçosa, 1971. 
Ribeiro MP, Mello K de, Valente RA. Landscape structure aiming at the biodiversity conservation of urbanized landscape. Ciência Florestal. 2020;30(3):819-834. doi: 10.5902/1980509837683

Salomão NV, Machado ELM, Pereira RS, Fernandes GW, Gonzaga APD, Mucida DP, et al. Structural analysis of a fragmented area in Minas Gerais State, Brazil. Anais da Academia Brasileira de Ciências. 2018;90(4):3353-3361. doi: 10.1590/00013765201820160828

Santos PA. Avaliação do padrão de exatidão cartográfica em imagens Ikonos e CBERS-2B na bacia do ribeirão São Bartolomeu, em Viçosa-MG [monografia]. Viçosa, MG: Universidade Federal de Viçosa. Viçosa, 2008.

Sarcinelli TS, Fernandes Filho EI, Schaefer CEGR, Marco Júnior P de, Leite FP. Soil and physiographic representativeness of native forest fragments in eucalyptus plantation areas. Revista Árvore. 2012;36(3):499-509. doi: 10.1590/S010067622012000300012

Schackelford N, Standish RJ, Lindo Z, Starzomski $\mathrm{BM}$. The role of landscape connectivity in resistance, resilience, and recovery of multitrophic microarthropod communities. Ecology. 2018;99(5):1164-1172. doi: 10.1002/ecy.2196

Silva GJ da, Fraga MS, Silva DD da. Study of flow regulation capacity in the São Bartolomeu River basin for water supply. Nativa. 2020;8(1):102-111. doi: 10.31413/nativa.v8i1.8251

Souza PB de, Meira Neto JAA, Souza AL de. Diversity and phytosociological structure of a topographic gradient in seasonal semidecidual forest of mata mumbaça, MG. Cerne. 2013;19(3):489-499. doi: 10.1590/S0104-77602013000300017

Toledo RM, Santos RF, Verheyen K, Perring MP. Ecological restoration efforts in tropical rural landscapes: Challenges and policy implications in a highly degraded region. Land Use Policy. 2018;75:486-493. doi: 10.1016/j. landusepol.2018.03.053

Veloso HP, Rangel Filho ALR, Lima JCA. Classificação da vegetação brasileira adaptada a um sistema universal. Rio de Janeiro: Instituto de Geografia e Estatística; 1991. ISBN 85-240-0384-7 